\title{
Türk Dünyasının Turizm Alanında İşbirliği Girişimleri: Bir Doküman İncelemesi ${ }^{1}$
}

\author{
Nazım ÇOKIŞLER ${ }^{2}$
}

\section{$\ddot{O} z$}

Türk Dünyası ekonomilerinin birbirine entegre edilmesi, devletler arasında yaygın ve derin kaynaşmanın sağlanması için turizm, en önemli işbirliği alanlarından biridir. Türk Dünyasında turizm alanındaki işbirliği çabaları Türk Konseyi ve Birleşmiş Milletler Dünya Turizm Örgütü (UNWTO) olmak üzere iki koldan ilerlemektedir. Araştırmada bu iki örgütün karar ve eylemleri topluca değerlendirilmiş, turizm alanındaki işbirliği çabalarının tarihi gelişimi ortaya konmuştur. Türk Dünyasının içsel dinamikleri içinde İpek Yolu Ortak Tur fikri ilk defa 1996 yllında Türkçe Konuşan Ülkeler Devlet Başkanları Zirvesinde gündeme gelmiş, bu fikir Modern İpek Yolu Ortak Tur Paketi projesiyle 2014 yılında Türk Konseyi tarafından somutlaştırılmıştır. 2019 yılında operasyonel hale gelmesi beklenen proje, COVID-19 sebebiyle sekteye uğramıştır. UNWTO İpek Yolu Tur Programı ise ilk defa 1994'de gündeme gelmiş, yeterli ivmenin kazanılamaması sebebiyle programda 2010 yılında yapısal, 2018 yılında felsefi bir değişime gidilmiştir. Araştırmanın bulguları başlangıçta niyetlilik bildirileri şeklindeki kararların zamanla daha somut bir hal aldığını, Modern İpek Yolu Ortak Tur Paketi'nin turizmde işbirliği için en öne çıan proje olduğunu ancak, Türk Konseyi ve UNWTO'nun tüm çabalarına rağmen bölge turizminde istenen sonucun alınamadığını göstermiştir.

Anahtar Kelimeler: Modern İpek Yolu Ortak Tur Paketi, İpek Yolu Turizmi, Türk Dünyası

\section{Cooperation Initiatives of Turkic World in Tourism: A Document Analysis}

\section{Abstract}

Tourism is one of the most important areas of cooperation in joining the economies of the Turkic world as well as in widespread and firm coalescing among the relevant states. Efforts of the Turkic world to cooperate in tourism have been progressing over two courses as the Turkic Council and United Nations World Tourism Organization (UNWTO). This paper presents an overall evaluation of the resolutions and actions of two organizations and historical development of collaborative efforts in tourism. Stemming from the internal dynamics of Turkic world, the idea of "Silk Road Joint Tour" was brought forward initially in 1996 as an agenda item at the Summit of Turkic Speaking States' Heads, and was substantiated in 2014 by the Turkic Council through a project titled "Modern Silk Road Joint Tour Package". The project was expected to be implemented in 2019, but it came to a standstill because of COVID-19. The UNWTO Silk Road Tour Program, on the other hand, gained currency in 1994; however, failure to gather sufficient momentum led to a structural and a philosophical change in the program in 2010 and 2018 , respectively. The results of this research study show that what initially were decisions akin to pronouncements of willingness became more concrete over time; that Modern Silk Road Joint Tour Package has been the landmark project in terms of cooperation in tourism, but that the desired outcome for tourism in the relevant region could not be achieved despite all endeavors by the Turkic Council and UNWTO.

Key Words: Modern Silk Road Joint Tour Package, Silk Road Tourism, Turkic World

\section{Atıf İcin / Please Cite As:}

Çokişler, N. (2021). Türk dünyasının turizm alanında işbirliği girişimleri: Bir doküman incelemesi. Manas Sosyal Arasttrmalar Dergisi, 10 (ÖS), 125-136.

Geliş Tarihi / Received Date: 19.09.2021

Kabul Tarihi / Accepted Date: 27.12.2021

\footnotetext{
${ }^{1}$ Bu makale I. Uluslararası Türk Dünyası Turizm Sempozyumu'nda sunulan “Modern İpek Yolu Ortak Tur Projesi’nin Hayata Geçirilmesi İçin Bir Öneri: İpek Yolu Kültürel Miras Uzman Rehber Eğitim ve Sertifika Programı” adlı bildirinin bir bölümü geliştirilerek hazırlanmıştır.

2 Dr. Öğretim Üyesi - İzmir Kâtip Çelebi Üniversitesi Turizm Fakültesi, cokisler@hotmail.com

iD ORCID: 0000-0003-3273-7472
} 


\section{Giriş}

Sovyet Sosyalist Cumhuriyetler Birliği'nin (SSCB) 1991 yılında dağılması ile birlikte, Türk devletleri arasında her alanda bir yakınlaşma süreci başlamış ve devletler ekonomi, eğitim, bilim, turizm ve kültür gibi alanlarda işbirliği arayışlarına girmişlerdir. Türk devletleri arasındaki işbirliği arayışlarını, küresel ve bölgesel diğer işbirliklerinden ayrı ve özel kılan husus, Türk devletleri arasındaki tarih ve dil birliğine dayanan ortak kültürdür.

Türk Dünyası'nın birleşme arayışı, Sovyetler Birliği’nin dağılma sürecine girmesi ile birlikte Türkiye Cumhurbaşkanı Turgut Özal'ın “Adriyatik'ten Çin Denizine Türk Dünyası” hedefi (Daban, 2017, s. 84) ve dönemin Başbakanı Demirel’in; "Bir ucu Adriyatik Denizi'nde, bir ucu Çin Seddi’nde olan bir Türkiye meydana gelmiştir" (Cumhuriyet, 1992) yorumu ile şekillenmiştir. Dönemin yöneticilerinin bu görüşleri Türk Dünyası'nın işbirliği arayışında Türkiye'nin aktif bir rol oynamasını sağlamış, ilk girişimler Türkiye'nin liderliğinde başlamış (Oran, 2003, s. 371) ve ülkeler arasındaki seyahatin kolaylaştırılabilmesi için vize muafiyeti ve direkt uçuşlar gibi konulara öncelik verilmiştir.

Türkiye, Azerbaycan, Türkmenistan ve Kazakistan ile vize muafiyeti konusunda ilk ikili anlaşmalar 1992'nin ilk aylarında yapılmış (Dışişleri Bakanlığı, 2021), böylece ülkeler arasındaki insan hareketliliğinin önündeki engellerin kaldırılması hedeflenmiş, ilk direkt uçuşlara ise 1992 Mayıs ayından itibaren Ankara ve İstanbul ile Türk Dünyası başkentleri arasında başlanmıştır (Oran, 2003). 5 Ekim 1992'de Taşkent'te Özbekistan; 7 Ekim 1992'de Bişkek'te Kırgizistan; 19 Ağustos 1992'de Ankara'da Türkmenistan ve 1 Kasım 1992'de Azerbaycan ile Türkiye arasında imzalanan ilk ikili anlaşmalar Türk Dünyasındaki turizm alanında yapılan ilk anlaşmalar olmuştur (Dışişleri Bakanlığı, 2021). Anlaşmalarda; ortak projeler geliştirmek, tecrübe alışverişinde bulunmak, işbirliğini teşvik edecek ve kolaylaştıracak tedbirler almak ve resmi temsilcilerin düzenli toplantılar yapması gibi kararlar yer almıştır (Türkiye Cumhuriyeti Hükümeti ile Özbekistan..., 1992; Türkiye Cumhuriyeti ile Kırgizistan..., 1992; Türkiye Cumhuriyeti Hükümeti ile Türkmenistan..., 1992; Türkiye Cumhuriyeti Hükümeti ile Azerbaycan..., 1992).

Türk devletleri arasında işbirliğini geliştirmeye yönelik atılan ilk adımların üzerinden çeyrek asırdan fazla bir zaman geçmiş, işbirliği çabaları; ekonomi, uluslararası ilişkiler, tarih, turizm, halkbilimi gibi çeşitli alanlardan gelen araştırmacılar tarafından farklı yönleri ile ele alınmış ve kapsamlı sayılabilecek bir alanyazın ortaya çıkmıştır. Türk Dünyası ve turizm konulu araştırmalar içinde; tanınırlık ve imaj sorunları (Gülcan, 2016; Zorlu, 2018), Modern İpek Yolu Projesi/Turu ve Türk Dünyası Kültür Başkenti Projesi (Oktay, 2016; Polat, 2018; Karadağ ve Savaşkan, 2018; Camgöz, 2019; Deniz ve Karadağ, 2019), Türk Dünyası'nın ulaştırma ağları (Camgöz ve Dinçer, 2017), destinasyonların ve konaklama sektörünün turizm etkinlikleri (Göral ve Tengilimoğlu, 2018; Dinçer, Bayram ve Bayram, 2019), Türk Dünyası turizmi cephesinden otantiklik arayışı (Bulut ve Gülcan, 2018), devlet dışı aktörlerin rolü ve önemi (Türk, 2015) gibi konular ele alınmıştır.

Alanyazında dikkati çeken eksiklik, turizm alanındaki işbirliği arayışlarının tarihsel gelişimini ele alan ve topluca değerlendiren araştırmaların azlığıdır. Bu konuda yapılmış bir araştırmada Türkiye'nin Asya ülkeleri ile yaptı̆g turizm anlaşmaları dış politika açısından değerlendirilmiş, bu ülkeler arasında Türk Devletleri de yer almıştır. Söz konusu araştırmanın bulgularına göre; turistik ürünlerin geliştirilmesi için bilgi, uzman ve deneyim paylaşımı, turizm eğitimine önem verilmesi, tanıtım gezileri yapılması ve gelişimlerin takip edilebilmesi için çeşitli komisyonlar kurulmasının önemi gibi öneri ve istekler tüm anlaşmalarda ortak olarak yer almıştır (Aydemir ve Yaşar, 2016, s. 56). Araştırmanın sonunda ortaya çıkan duruma göre, en çok anlaşma yapılan ülkeler arasında olmasına rağmen Çin Halk Cumhuriyeti’nden ya da en eski tarihli anlaşmalardan birinin imzalanmış olmasına rağmen Pakistan'dan Türkiye'ye gelen turist sayısı istenen düzeyde olmaktan uzaktır. Bu bulgu, turizm anlaşmalarının tek amacının ekonomik fayda sağlamak olmadığı, "uzun vadeli dış politika stratejisi çerçevesinde ekonomik, politik, kültürel, dini, vb. sebeplerle imzalandığı" şeklinde yorumlanmıştır (Aydemir ve Yaşar, 2016, s. 57).

Mevcut araştırma Türk Dünyası'nda turizm alanında gerçekleştirilmesi hedeflenen işbirliği çabalarının gelişimini ortaya koyma amacındadır. Bu amaçla, çeşitli tarihlerde yapılan zirve ve toplantılarda alınan kararlar doküman analizi yoluyla incelenmiş, bulgular "Türk Konseyi'nin Girişimleri" ve "UNWTO İpek Yolu Deklarasyonları ve İpek Yolu Programı" adlı iki ana bölümde sunulmuştur. Sonuç ve değerlendirme bölümünde ise sunulan bulguların genel bir değerlendirmesi yapılmıştır. 


\section{Yöntem}

Türk Dünyası'nda turizm alanındaki işbirliği çabaları Türk Konseyi ve UNWTO olmak üzere iki farklı koldan ilerlemektedir. Taraflar arasında yapılan ikili anlaşmalar dışında, turizm alanındaki işbirliği arayışlarının izlenebildiği diğer resmi kaynaklar; Türk Konseyi kararları, Birleşmiş Milletler Eğitim, Bilim ve Kültür Örgütü (UNESCO) ile UNWTO öncülügünde hazırlanan İpek Yolu Deklarasyonları ve UNWTO İpek Yolu Programı'dır. Uzun zamandır devam eden işbirliği arayışında en öne çıkan proje ise Modern İpek Yolu Ortak Tur Paketi'dir ve bu paket hem Türk Konseyi hem de UNWTO tarafindan hayata geçirilmesi için en uzun zamandır uğraş verilen proje konumundadır. Bu nedenle araştırmada ilk olarak; 1992-2010 y1lları arasında düzenlenen Türkçe Konuşan Ülkeler Devlet Başkanları Zirveleri sonunda imzalanan bildiriler, 2011 yllinda kurulan Türk Konseyi'nde ve 2014'ten beri düzenlenmekte olan Turizm Bakanları toplantılarında alınan kararlar, ardından, UNESCO önderliğinde hazırlanan beş adet İpek Yolu Deklarasyonu ile UNWTO İpek Yolu Programı kararları incelenmiş, böylece, Birleşmiş Milletlerin Türk Dünyası'nda turizmi geliştirme çabalarl; deklarasyonlar ve kurulan görev gücünün aldığ1 kararlar doğrultusunda açıklanmıştır.

\section{Bulgular}

\section{Türk Konseyi'nin Girişimleri}

\section{Türkçe Konuşan Ülkeler Devlet Başkanları Zirveleri}

1992'den 2010'a kadar geçen on sekiz yılda düzenlenen toplam on zirve Türkçe Konuşan Ülkeler Devlet Başkanları Zirveleri olarak anılmaktadır. 1991 yılında SSCB’nin dağılmasının hemen ardından ortak hareket etmenin önemini kavrayan Türk devletleri, bu zirvelerle özellikle kültür ve eğitim alanlarında aralarındaki işbirliğini geliştirme yolları arayışına girmişlerdir (Tablo 1).

Tablo 1. Türkẹe Konuşan Ülkeler Devlet Başkeanlar Zirveleri

\begin{tabular}{lll}
\hline Zirve No & Tarih & Yer \\
\hline 1. Zirve & 30-31 Ekim 1992 & Ankara/Türkiye \\
2. Zirve & 18-19 Ekim 1994 & İstanbul/Türkiye \\
3. Zirve & 27-29 Ağustos 1995 & Bişkek/Kurgizistan \\
4. Zirve & 19-21 Ekim 1996 & Taşkent/Özbekistan \\
5. Zirve & 9 Haziran 1998 & Astana/ Kazakistan \\
6. Zirve & 8 Nisan 2000 & Bakü/Azerbaycan \\
7. Zirve & 26-27 Nisan 2001 & İstanbul/Türkiye \\
8. Zirve & 17 Kasim 2006 & Antalya/Türkiye \\
9. Zirve & 2-3 Ekim 2009 & Nahçvan/ Azerbaycan \\
10. Zirve & 16 Eylül 2010 & İstanbul/Türkiye \\
\hline
\end{tabular}

Zirvelerin sonunda imzalanan bildirilerin tümünde "Türk dili konuşan halkların, ortak tarih, dil, kültür ve gelenekleri temelindeki dayanışmasını daha da güçlendirme ve pekiştirme arzusu" teyit edilmiştir. 1992 yllında düzenlenen ilk zirveden itibaren, kültür kurumları arasındaki işbirliğinin geliştirilmesi ve ortak kültür mirası eserlerinin korunması, onarımı ve tanıtılması için işbirliği yapılmasının önemi vurgulanmaya başlanmıştır (md. 8). Bu dönemde, sadece turizm alanında değil, ilişkilerin genel olarak güçlendirilmesi ve derinleştirilmesi için aktif ve girişimci bir diş politika izleyen Türkiye, diğer devletlere kıyasla daha ön planda yer almıştır. Türkiye'nin işbirliği arayışındaki çabası, on zirvenin beşine ev sahipliği yapmasında görülebilmektedir. Eğitim, bu dönemde geliştirilen dış politika stratejilerinin en önemlilerinden birisi olmuş, imzalanan ikili anlaşmalar sayesinde, bağımsızlığına kavuşan Orta Asya Türk Cumhuriyetleri ile öğrenci değişimi ve ortak eğitim yatırımları teşvik edilmiştir.

Tarafların ekonomilerinin birbirine entegre edilmesi için turizm en önemli alanlardan biridir (Hasanov, 2015). 1996 tarihli dördüncü zirve turizm alanında ilk kararların alındığı zirvedir ve zirvede "İpekyolunun İhyası: Kültür Turizminin Geliştirilmesi, Türkçe Konuşan Devletlerin Kültürel Mirasının Canlandırılması, Korunması ve İstikrarlı Bir Biçimde Geliştirilmesi” adlı bir programın oluşturulması kararlaştırılmıştır (md. 5). 1998 tarihli beşinci zirvede İpek Yolu'nun Canlandırılması Programı’nın bölge ekonomisi açısından önemli bir rol oynayacağı ve ekonomik işbirliğini güçlendirileceği vurgulanmıştır (md. 4). 2000 tarihli altınc1 zirvede, ilişkilerin geliştirilmesinin istendiği alanlar arasında eğitim, kültür ve turiz̨m alanları ayrı ayrı zikredilmiş (md. 9) ve "tarihi Büyük İpek Yolu’nun yeniden canlandırılmasının ekonomik potansiyelin geliştirilmesinde önemli rol oynayacă̆g” bir kez daha belirtilmiştir (md. 4). 2001 yllında yapılan 
yedinci zirvede Büyük İpek Yolu'nun canlandırılması çalışmalarının hızlandırılmasına vurgu yapılmış ve "bu çerçevede kaydedilecek gelişmelerin bölgede ekonomiye ve turizme katkıda bulunacağına" dair inanç dile getirilmiştir (md. 4). 2006 yılında yapılan sekizinci zirvede turizm alanındaki işbirliği istekleri yeniden dile getirilmiş (md. 17) ve "insancıl temasları artırmak [adına] yurttaşlarının birbirlerinin ülkesine yapacağ1 yolculukları kolaylaştırmak ve özendirmek amacıyla vize işlemlerinin basitleştirilmesi ve hızlandırılması doğrultusunda çaba göstermeye hazır oldukları" bildirilmiştir (md. 17). 2009 yılındaki dokuzuncu zirvede, işbirliğinin geliştirilmesi için "iilave tedbirler alınmasına ihtiyaç duyulduğu" belirtilmiş (md. 5), "bilim, eğitim, kültür, sanat, turizm, spor ve diğer alanlardaki ilişkilerin geliştirilmesinin karşl1ıklı yararı" teyit edilmiş ve "Türk Dili Konuşan Halklar arasındaki dini ve beşeri temasların güçlendirilmesini[n]" desteklendiği kaydedilmiştir (md. 9). Tarafların "ortak kültürel mirasın korunması ve gelecek nesillere aktarılması ve uluslararası arenada tanıtımının yapılması amacıyla işbirliğinde bulunmak üzere çaba sarf edecekleri” belirtilmiştir (md. 29). Dokuzuncu zirvede ayrıca Türk Dili Konuşan Ülkeler İşbirliği Konseyi'nin kurulması kararlaştırılmış ve bu konseyin taraf ülkeler arasındaki ilişkilerin güçlenmesinde "yeni bir aşama teşkil ettiğ̣”" belirtilmiştir (md. 28). 2010 tarihli onuncu zirvede, işbirliğinin geliştirilmesi istenen sektörler arasında turizm sektörü bir kez daha sayılmıştır (md. 22). Eğitim, kültür ve turizm alanlarındaki ilişkilerin geliştirilmesinin yararlı olacağı ve halklar arasındaki beşeri temasların gelişmesine taraf ülkelerin gençlik birliklerinin katkıda bulunacağı beklentisi dile getirilmiştir (md. 27). Ayrıca, etnikkültür ve etnik-turizmin desteklenme ihtiyacı vurgulanmıştır (md. 30). Ayrıca, Türk Dünyası Kültür Başkenti projesinin hayata geçirilmesi ve 2012 yllında Kazakistan'ı Astana şehrinin ilk başkent olarak ilan edilmesi kararlaştırllmışır (md. 17). 2012'den beri her y1l farklı bir şehir Türk Dünyası Kültür Başkenti olarak ilan edilmekte ve o yılın kültürel faaliyetlerinin merkezi konumuna gelmektedir (Tablo 2).

Tablo 2. Türk Dünyası Kültür Başkentleri

\begin{tabular}{lll}
\hline $\boldsymbol{Y l}$ & Ülke & Şehir \\
\hline 2012 & Astana & Kazakistan \\
2013 & Eskişehir & Türkiye \\
2014 & Kazan & Tataristan \\
2015 & Merv & Türkmenistan \\
2016 & Seki & Azerbaycan \\
2017 & Türkistan & Kazakistan \\
2018 & Kastamonu & Türkiye \\
2019 & Oş & Kirgizistan \\
2020 & Hiva & Özbekistan \\
2021 & - & - \\
2022 & Bursa & Türkiye \\
\hline
\end{tabular}

Zirveler genel olarak değerlendirildiğinde, 1992-2010 dönemin işbirliği arayışının kurumsallaştırılması çabaları ile geçtiği söylenebilir. İlk bildirilerde işbirliğinin önemini ve işbirliğini geliştirme konusunda mevcut iyi niyeti vurgulayan genel ifadeler, yerini zamanla, daha somut projelere bırakmış, en somut adımlar kültür ve eğitim alanlarında atılmıstır (Mert, 2015). Turizmde işbirliğinin geliştirilmesi çabalarında ise ilk somut proje 1996 yllında ortaya atılan İpekyolu'nun İhyası projesi olmuş ancak projenin hayata geçirilmesi için gerekli adımlar bu dönemde atılamamışır.

\section{Türk Konseyi Zirveleri}

27 Nisan-3 Mayıs 1992 tarihlerinde dönemin Başbakanı Süleyman Demirel'in Türk devletlerine yaptığı gezi sırasında gündeme gelen, dönüşümlü olarak her yıl bir devletin başkanlığını yürüteceği bir Konsey kurulması fikri (Oran, 2003) 2009 yllında hayata geçebilmiştir. Dokuzuncu zirvede alınan kararla kurulan ve Türk dili konuşan devletler arasındaki ilişkilerde yeni bir aşama olarak anılan Türk Konseyi tarafların işbirliği arayışındaki önemli bir adımdır. Kısa adı Türk Konseyi olan Türk Dili Konuşan Ülkeler

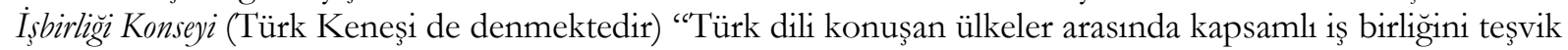
etmek amacı ile uluslararası bir örgüt olarak" kurulmuştur (Mert, 2015, s. 276). Türk Konseyi 2011-2021 yılları arasında farklı tema başlıkları altında sekiz zirve gerçekleştirmiştir (Tablo 3).

2014 tarihli dördüncü zirve Turizm Alannda İsbirliği temasıyla Haziran ayında Bodrum'da düzenlenmiş, "devletler arasında oluşturulmaya çalışlan çok boyutlu ve derinlikli işbirliği sürecinde [turizmin] ayrıcalıklı bir yere sahip olduğu" düşüncesiyle bu tema seçilmiş ve "tarihi İpek Yolu'nun cazip bir turizm destinasyonuna dönüştürülmesi” önemli bir hedef olarak belirlenmiştir (Türk Keneşi, 2021b). Zirve sonunda hazırlanan bildiride turizm alanındaki kararlara Ekonomi Alanında İşbirliği başlığ altında yer verilmiştir: Taraflar 11 Nisan 2014 tarihinde İstanbul'da gerçekleştirilen Türk Konseyi Turizm Bakanları 
Birinci Toplantısı raporunu memnuniyetle karşılamıştır (md. 1). "Turizm sektöründe artan işbirliğinin sadece Üye Ülkelerin değil aynı zamanda üçüncü tarafların da bölgeye ilgisinin canlandırlmasına hizmet edeceği" vurgulanmıştır (md. 2). "Turizm alanında işbirliğinin daha da güçlendirilmesi ihtiyacının" altı çizilmiştir (md. 3). Turizm Alanında Ortak İşbirliği Protokolü’nün üye ülkelerin turizmden sorumlu bakanları tarafindan imzalanması ve Türk Konseyi himayesinde bir ortak turizm iş birliği kurulması kararı memnuniyetle karşılanmışır (md. 5). Modern İpek Yolu tur programı düzenlenmesi, bu tur için bir rehber kitap hazırlanması ve tur programının güzergâhının belirlenmesi için ortak bir görev gücü kurulması yönündeki kararlardan duyulan memnuniyet dile getirilmiş, ayrıca, ortak gezi programının gerçekleştirilmesi ve tanıtımı için üye ülke kamu ve özel kurumları gerekli tedbirleri almaya çağrılmıştır (md. 6). Türkiye'nin diğer üye ülkeler için turizm eğitim programları düzenlemesi memnuniyetle karşlanmıştır (md. 7).

Tablo 3. Türk Konseyi Zirveleri ve Temalar

\begin{tabular}{lll}
\hline Tarih & Yer & Tema \\
\hline 20-21 Ekim 2011 & Almatı/Kazakistan & Ekonomik Issbirliği \\
22-23 Ağustos 2012 & Bişkek/Kirgızistan & Eğitim, Bilim ve Kültürel İşbirliği \\
15-16 Ağustos 2013 & Gebele/Azerbaycan & Ulaştırma ve Bağlantı \\
4-5 Haziran 2014 & Bodrum/Türkiye & Turizm Alanında İşbirliği \\
11 Eylül 2015 & Astana/Kazakistan & Medya ve Enformasyon Isşbirliği \\
3 Eylül 2018 & Çolpon-Ata/Kırgızistan & Gençlik ve Ulusal Sporlar \\
15 Ekim 2019 & Bakü/Azerbaycan & Küçük ve Orta Büyüklükteki Isşletmelerin Desteklenmesi \\
10 Nisan 2020 & Bakü/Azerbaycan & COVID-19 Küresel Salgını ile Mücadelede Dayanışma ve İsbirliği \\
\hline
\end{tabular}

2018 Çolpon-Ata Zirvesi Gençlik ve Ulusal Sporlar Issbirliği temasıyla Kırgızistan'da toplanmıştır. Zirvede ön plana çıkan konu Kırgızistan tarafindan düzenlenen ve hem taraflar arasında diyalog, barış ve kalkınmayı güçlendirmesi hem de kadim kültür ve geleneklerin sergilenmesi ve dünyaya tanıtılması için önemli bir araç olan Dünya Göçebe Oyunları olmuştur. Turizm alanında yürütülen girişimlerin somutlaşmaya başladığı bir dönemde düzenlenen zirvede "Üye Ülkelerin ortak kültürel ve tarihi mirasını ortaya çıarmak için eşsiz bir turizm projesi olan Türk Konseyi Modern İpek Yolu Ortak Tur Paketi'nin hayata geçirilmesinden [duyulan] övünç" ifade edilmiş, üye devletlerin tur paketine verdikleri finansal desteği artırmaları çağrısı yapılmış, turu mali açıdan cazip hale getirebilmek için başta ulusal hava yolu şirketleri olmak üzere özel sektörün desteği istenmiştir (md. 23). 2019 Bakü Zirvesi Kü̧̈ük ve Orta Büyüklükteki İsletmelerin (KOBI'lerin) Desteklenmesi temasıyla toplanmış, Modern İpek Yolu Ortak Tur Paketi'nin ulusal ve uluslararası fuarlarda birlikte tanıtılması teşvik edilmiş (md. 31), hava yolu şirketlerinin projeye destek vermesi çağrısı yenilenmiştir (md. 32). Ayrıca, İpek Yolu turizminin geliştirilmesi için Türk Konseyi ile UNWTO arasındaki işbirliğinin geliştirilmesi yönünde çağrıda bulunulmuştur (md. 37.d). 2020 tarihli son zirve, salgın döneminde video konferans şeklinde yapılmış, salgınla mücadelede işbirliği konusu ele alınmış, Modern İpek Yolu Ortak Tur Paketi’nden bahsedilmemiştir.

Görüldüğü üzere, turizm alanındaki işbirliği arayışları eğitim ve kültür alanında atılan adımların gerisinde kalmış, Türk devletlerinin bu alanlardaki çabalarında, Avrupa Birliği tarafindan denenmiş ve olumlu sonuçlar alınmış yöntemler tercih edilmiştir. Bu anlamda TÜRKSOY, UNESCO'yu; Orhun Değişim Programı, Erasmus Değişim Programını; Türkvizyon Şarkı Yarışmas1, Eurovision'u; Türk Dünyası Kültür Başkentleri Projesi, Avrupa Kültür Başkentleri Projesini örnek alarak oluşturulmuş girişimlerdir (Purtaş, 2017).

Turizm alanında atılan en somut adım Modern İpek Yolu Ortak Tur Paketi'dir. İlk defa 1996 ylında gündeme gelen İpek Yolu Ortak Tur fikrinin hayata geçmesi 2014'te düzenlenen zirvenin temasının turizm olarak belirlenmesi sayesinde başlamıştır. Ortak Tur Paketi'nin gelişimi Turizm Bakanları Toplantıları'ndan izlenebilmektedir.

\section{Turizm Bakanlant Toplantıları}

Türk Dünyası'nda turizm alanında yapılması planlanan işbirliğinin yürütücüsü üye ülkelerin turizmden sorumlu bakanlarının 2014-2021 yılları arasında gerçekleştirdikleri toplantılarıdır. 2014'te düzenlenen Bodrum Zirvesi’nin Turizm Alaninda İşirliği temasiyla düzenlenmesine karar verildikten sonra, turizm alanındaki işbirliklerinin artırılması için üye ülkelerin turizm bakanlarının düzenli olarak buluşmasına karar verilmiş, bu karar doğrultusunda ilk toplantı 11 Nisan 2014'te İstanbul'da toplanmıştır. Birinci Bakanlar toplantısında; ortak mesleki eğitimlerin başlaması, üye ülkelerin özel sektörleri için turizm hareketlerini 
kolaylaştıracak tedbirlerin alınması ve uluslararası kuruluşlarla işbirliğinin geliştirilmesi gibi konular ele alınmıştır. Bu girişimleri somutlaştırmak için Türk Keneşi Üye Devletleri Arasında Turizm İşbirliği Ortak İşbirliği Protokolü Bodrum Zirvesi'nde devlet başkanları tarafindan imzalanmışırı (Türk Keneşi, 2014). Protokol ile İpek Yolu Ortak Tur Paketi projesinin genel hatları belirlenmiş, 2018 yllinda faaliyete geçecek şekilde (Yılmaz, 2019) projenin geliştirilmesi üzerine çalışmalar yapması için Kazakistan'ın başkanlığında bir Görev Gücü kurulmasına ve tur güzergâhının 2015 yılı içinde belirlenmesine karar verilmiştir.

İkinci Turizm Bakanlar Toplantısı 20 Mayıs 2015'te Bakü'de yapılmıştır. Ortak Tur Paketi'nin hazırlık ve tanıtım çalışmalarının değerlendirildiği toplantıda, üye ülkelerde faaliyet gösteren özel sektör temsilcilerinin katılımı ile Üye Devletlerin Özel Sektör Şemsiye Kurumları Arasında İşbirliği Protokolü imzalanmıştır (Türk Keneşi, 2015; Türk Keneşi, 2021a). Turizm Bakanları Toplantısı üçüncü kez 2016'da Kırgızistan'ın Çolpan-Ata kentinde yapılmış, UNWTO Genel Sekreteri Taleb Rıfai'nin de katıldığı toplantıda Türk Konseyi ve UNWTO arasında işbirliğinin İpek Yolu turizmi aracilığıyla geliştirilmesi benimsenmiştir. Türk Konseyi Üye Devletlerinden on bir tur operatörü, üyelerin Turizm Bakanları ve UNWTO Genel Sekreteri Rıfai'nin huzurunda BM Turizm Etik Kodu'nu imzalamıslardır. 21 Aralık 2001'de BM Genel Kurulu'nda, turizmin çevre ve kültürel miras üzerindeki olumsuz etkilerini azaltmak ve yerel halkın turizmden en yüksek faydayı elde etmesini sağlamak amacında olan turizm etik kodları (UNWTO, 2021a) böylece Türk Dünyası turizmi için de kabul edilmiştir.

Dördüncü Turizm Bakanları Toplantısı 2018 yllında Astana'da düzenlenmiş, toplantının başlıca konusu tanıtılmaya başlanan Modern İpek Yolu Ortak Tur Paketi olmuş, sonraki yllın turizm sezonu için gerekli reklam ve pazarlama stratejileri üzerinde durulmuştur (Türk Keneşi, 2021a). Turda görev alacak turist rehberlerinin 2018 yılı sonunda eğitimine başlanması için bir eylem planı hazırlanması da toplantıda karara bağlanmış, toplantıya onur konuğu olarak katılan Özbekistan yetkililerine İpek Yolu güzergâhında yer alan Özbek şehirlerinin pakete dâhil edilmesi yönünde çağrıda bulunulmuştur (Türk Keneşi, 2018).

Türkiye Cumhuriyeti Kültür ve Turizm Bakanlığı ev sahipliğinde yapılması planlanan turizmden sorumlu bakanların beşinci toplantısı, Türk Konseyi üyeleri ve gözlemci ülke Macaristan'ın katılımıyla 2223 Haziran 2020'de COVID-19 Salgını sebebiyle video konferans yoluyla yapılmış ve salgının turizm üzerindeki etkileri ve sektörün tekrar faaliyete geçmesi için düşünülen tedbirler ele alınmıştır. Altınc1 Turizm Bakanları Toplantısı 24 Haziran 2021 tarihinde Özbekistan'ın Kokand şehrinde yapılmış, dünyada ve Türk Dünyası'nda turizm alanındaki gelişmelerin ele alındığı toplantıda, pandeminin turizm sektörü üzerindeki etkileri değerlendirilmiştir. Toplantıda, Türk Dünyası kültür başkenti uygulamasından farklı olarak her yll bir Türk Dünyası şehrinin turizm başkenti olarak seçilmesine karar verilmiş, Özbekistan'ın Kokand şehri 2021 yllı için Türk Dünyası'nın ilk turizm başkenti olmuştur (Türk Keneşi, 2021c).

İpek Yolu Ortaçağ boyunca, sadece, insan ve malların değil, kültürün ve medeniyetin de Orta Asya ile Avrupa arasında taşınmasını sağlayan bir güzergâh olmuştur (Purtaş, 2011). Günümüzde Modern İpek Yolu Projesi ile bu güzergâhta sadece ticaret değil, kültür ve medeniyetin akışı da tekrar canlandırılmaya çalışılmaktadır. Bu kapsamda, coğrafi ve kültürel çekicilikleri ile önemli bir çekim merkezi haline gelebilecek olan Orta Asya'nın bu potansiyelinin ortaya çıkarılması ve kullanılması için Türk Konseyi tarafindan geliştirilmiş en somut proje Modern İpek Yolu Ortak Tur Paketi'dir. Projenin bölgenin dünyaya tanıtılması ve kalkınmasında önemli bir araç olması hedeflenmektedir (Baki, 2014). Bölgenin sosyoekonomik kalkınmasını sağlamada en önemli itici güçlerden biri olacağı düşünülen tur, Türk Konseyi Genel Sekreteri Ramil Hasanov tarafindan turizm alanında birincil öncelikli gündem maddesi olarak ifade edilmiştir (Hasanov, 2015). 2017 yllında bahsi geçen turun tanıtımı için ilk tanıtım gezileri düzenlenmiş, Türk Konseyi üye devletlerinin yanı sıra, Belçika, İtalya, ABD, Birleşik Krallık, İspanya, İran, Singapur, Fransa, Almanya, Avusturya, Katar, Polonya olmak üzere 16 ülkeden, basın mensuplarn, akademisyenler, tur operatörleri ve bloggerlar gibi farklı sektörlerden toplam 59 katıllımcıya yönelik iki tanıtım turu yapılmıştır. Turlar, Kayseri'den başlayıp Bişkek'te sona erecek şekilde 14 gün sürmüş, ilk tur 21 Nisan-5 Mayıs ve ikincisi 12-26 Mayıs tarihleri arasında düzenlenmiştir. Turlar Türkiye Cumhuriyeti Tanıtma Fonu tarafindan finanse edilmiş, ulaşımda ana sponsor Türk Hava Yolları, diğer sponsorlar Kazakistan ulusal havayolu şirketi olan Air Astana ve Azerbaycan Havayolları olmuştur (Türk Keneşi, 2017a; Türk Keneşi, 2017b). Teknik hazırlıkları böylece tamamlanan tur paketinin tanıtım çalışmaları 2018 yllında başlamış, İspanya'da FITUR, Türkiye'de EMITT gibi uluslararası turizm fuarlarında tanıtılan tur büyük ilgi çekmiştir (Turizm Günlügü, 2018). 2019'da operasyonel hale gelmesi hedeflenen paket COVID-19 salginı ile sekteye uğramıştır. 


\section{UNWTO İpek Yolu Deklarasyonları ve İpek Yolu Programı}

Türk Konseyi'nin işbirliği arayışları dışında, UNWTO'nun da bölge turizmini geliştirme yönünde çabaları bulunmaktadır. Birleşmiş Milletler tarafindan kabul edilen Gündem 21 ve Gündem 2030 kapsamındaki sürdürülebilir kalkınma hedefleri içinde turizm önemli bir araç olarak zikredilmektedir (UNWTO, 2016). Sosyo-ekonomik kalkınmada turizme atfedilen önem UNWTO'yu bölgesel kalkınma planlarında önemli bir aktör haline getirmiş, bu nedenle İpek Yolu'nda turizmin geliştirilmesi için en çok çabalayan kuruluşlardan biri de UNW'TO olmuştur.

İpek Yolu'nda turizmin geliştirilme çabalarının ilk ayağı UNWTO ve UNESCO önderliğinde hazırlanan beş deklarasyondur. Bu deklarasyonlarda; bölgesel zenginlik ve istikrar için işbirliği yapılması, farklı paydaşların bir araya gelmesi ile güçlü bir turizm markası yaratılması, bölgenin doğal ve kültürel zenginliklerini öne çıkaran bir turizm konsepti geliştirilmesi esasları vurgulanmışır (UNWTO, 2021b).

1996 tarihli Dördüncü Türkçe Konuşan Ülkeler Devlet Başkanları Zirvesi’nden iki sene önce, 1994’te imzalanan Semerkand Deklarasyonu ile ilk defa, 19 ülke, İpek Yolu güzergâhındaki iç ve dış turizmi geliştirmek için ortak hareket edeceklerini bildirmişlerdir (UNWTO, 1994). UNWTO ve UNESCO yanında Avrupa Konseyi'nin de desteklediği 1999 Khiva Deklarasyonu, barış, zenginlik ve kültürler arası diyaloğu tesis etmede turizmin ve kültürel mirasın korunmasının önemini vurgulamıştır (UNWTO, 1999). 2002 Buhara Deklarasyonu'nda turizmin geliştirilmesi için atılması gereken adımlar arasında; vize kolaylıklarının sağlanması, turistik ürün çeşitlendirilmesi ve yerel halkın kültürel mirasa bakış açısının değiştirilmesi için eğitime önem verilmesi gibi öneriler yer almıştır (UNWTO, 2002). 2009'da Astana'da imzalanan deklarasyonda, vize ve gümrük zorluklarının aşılmasının önemi bir kez daha vurgulanmış, Birleşmiş Milletler Kalkınma Programı, UNESCO ve UNWTO'dan daha güçlü bir destek istenmesi kararlaştırılmıştır (UNWTO, 2009). 2010 Şiraz Deklarasyonu'nda İpek Yolu Belediye Başkanları Forum Sekretaryası'nın bölgesel İpek Yolu vizęesi konusunun da yer aldığı bir eylem planı hazırlamasi; kültürel ve bilimsel kuruluşlar arasında işbirliğinin geliştirilmesi; üye şehirlerde birer parka İpek Yolu adının verilmesi, parkların bu ada uygun sembollerle dekore edilmesi, ayrıca birer bulvara da İpek Yolu isminin verilmesi önerilmiştir (UNWTO, 2010a).

$\mathrm{Bu}$ deklarasyonlara rağmen, İpek Yolu turizmini geliştirme çabalarında 2010 yllına kadar somut adımlar atılamamış (UNWTO, 2010b), bunun üzerine UNWTO yeni bir dönem başlatmıştır. Bu tarihten itibaren İpek Yolu turizmini geliştirme çabaları çeşitli tarihlerde UNWTO tarafindan çıkarılan eylem planlarından ve bu planların uygulanmasından sorumlu İpek Yolu Görev Gücü’nün faaliyetlerinden izlenebilmektedir.

2010 yılında geliştirilen ilk eylem planı ile; pazarlama ve tanıtım, kapasite geliştirme ve destinasyon yönetimi ile seyahatin kolaylaştırllması üç öncelikli alan olarak belirlenmiştir (UNWTO, 2014). Bu amaçla İpek Yolu'nun uluslararası tanınırlığını artırmak için yürütülen pazarlama ve tanıtım faaliyetleri kapsamında turizm fuarlarında, yazılı, görsel ve sosyal medyada çeşitli faaliyetler yürütülmüsş; kapasite geliştirme ve destinasyon yönetimi için UNESCO ve Uluslararası Anttlar ve Sitler Konseyi (ICOMOS) gibi kuruluşlar aracilığıyla, güzergâh üzerindeki kültürel miras alan ve anıtlarının korunması ve geliştirilmesi için çeşitli planlar hazırlanmış, ayrıca, turist rehberleri için eğiticilerin eğitimi kapsamında mesleki eğitim programları başlatılmışıı. Uluslararası turistlerin yarıdan fazlasının gitmek istedikleri destinasyona havayolu ile ulaşması nedeniyle, UNWTO'nun önceliklerinden biri de bölge ülkeleri arasındaki havayolu bağlantılarının iyileştirilmesi olmuş (UNWTO, 2014), seyahatin kolaylaştırlması kapsamında; vize, sınır geçişleri ve vergilendirmede kolaylıklar yapılması için girişimlerde bulunulmuştur (UNWTO, 2016).

Eylem planlarının uygulanmasından sorumlu olan görev gücü ilk toplantısını 2011'de yapmış ve 2018’e kadar her yll düzenli olarak toplanmıştır. 2021 itibariyle 35 ülkenin ${ }^{3}$ yer aldığ1 görev gücünde 2018 yllıyla birlikte yeni bir felsefe ve eylem planı arayışı başlamışır. Bu tarihe kadar bütün ülkeleri kapsayacak bütüncül planlardan istenen verimin elde edilememesi üzerine, ülke odaklı yeni bir anlayışa geçilmiştir. $\mathrm{Bu}$ anlayışla, tek yönlü ve merkeziyetçi stratejiler yerine, her ülkenin kendi öncelik ve çıkarlarına uygun 2-4 yıllık projelerle turizmde kalkınma yol haritalarını belirlemesi hedeflenmektedir (UNWTO, 2018). Bu yeni anlayışın somut sonuçlarını değerlendirmek için henüz erkendir.

\footnotetext{
${ }^{3}$ Bu ülkeler şunlardır: Arnavutluk, Azerbaycan, Bangladeş, Bulgaristan, Çin, Endonezya, Ermenistan, Gürcistan, Hırvatistan, Irak, İran, İspanya, İsrail, İtalya, Japonya, Karadağ, Kazakistan, Kırgizistan, Kore Cumhuriyeti, Kore Demokratik Halk Cumhuriyeti, Malezya, Misır, Moğolistan, Özbekistan, Pakistan, Romanya, Rusya, San Marino, Suriye, Suudi Arabistan, Tacikistan, Türkiye, Türkmenistan, Ukrayna ve Yunanistan.
} 


\section{Tartışma ve Sonuç}

Bu araştırmada, Türk Dünyası'nın turizm alanında işbirliğini geliştirme çabaları Türk Konseyi ve UNWTO perspektifinden değerlendirilmiştir. İnceleme sonucu, Türk Dünyası'nda işbirliği arayışının Sovyetler Birliğg’’nin yıkılmasıyla başladığını, ilk anlaşmaların Türkiye'nin öncülüğünde yapıldığını, eğitim, kültür ve ekonomi başlıklarının yanında turizm konusunun da 1990'li yıllardan itibaren işbirliğinin geliştirilmesi istenen konular arasında yer aldığını göstermiştir.

Bu sürecin, Uluslararası Türk Kültürü Teşkilatı'nın 1993 yılında kurulmasından 2011 yllına kadar geçen kısmı, somut adımların atılabilmesi için gerekli siyasi iradenin ortaya konması, bunun için gerekli yasal zeminin hazırlanması ve ülkeler arasındaki eşgüdümü sağlayacak kurumların oluşturulması çalışmaları ile geçmiştir. Başlangıçta iyi niyet bildirisi şeklindeki kararlar zamanla daha somut bir hal almış, 2011 yılında, kısa adı Türk Konseyi olan Türk Dili Konuşan Ülkeler İşbirliği Konseyi’nin kurulmasının ardından başlayan ikinci kısımda ise; Türk Dünyası Kültür Başkentleri Projesi (2012), Türkvizyon Şarkı Yarışması (2013), Uluslararası Türk Dünyası Bilim ve Kültür Şenliği (2014), Orhun Değişim Program1 (2014) ve Göçebe Oyunları (2014) gibi somut projeler hayata geçirilmiştir.

Turizm alanındaki en somut proje ise Modern İpek Yolu Ortak Tur Paketi olmuştur. İncelemenin sonuçlarına göre, İpek Yolu turu fikri ilk defa, UNWTO öncülügünde 1994’te imzalanan Semerkand Deklarasyonu ile gündeme gelmiş, Türk Konseyi’nin çabaları ile Modern İpek Yolu Ortak Tur Paketi projesi geliştirilmiş, 2017 yılında turun ilk tanıtım gezileri düzenlenmiş, ancak, tur beklendiği gibi 2019 yllında operasyonel hale gelememiştir. UNWTO İpek Yolu Programı ise 2010 yılından beri çeşitli eylem planları ile geliştirilmeye çalışılmış, ancak arzu edilen seviyeye ulaşılamamış ve bunun üzerine 2018 yllında, ülke odaklı yeni bir anlayışa geçilmiştir. 2021'de düzenlenen Türk Konseyi Turizmden Sorumlu Bakanlar Altınc1 Toplantısı'nda alınan kararla başlatılan Türk Dünyası Turizm Başkenti girişiminin de, UNWTO'nun ortaya koyduğu yeni anlayışla paralellik sergilediği görülmektedir. Bu anlayışa uygun olarak, İpek Yolu Ortak Paketi'nin tüm güzergâhının toplu olarak turizme açılması yerine, ülke ve şehir bazlı projelere ağırlık verilmeye başlandığı sonucu ortaya çıkmaktadır. Bu bulgular, tüm çabalara rağmen, turizm alanında hedeflenen seviyeye henüz ulaşılamadığını, ilk zirvelerden itibaren dile getirilmeye başlanan ortak dil, tarih ve kültür vurgusunun Türk devletleri arasında, turizm alanında arzu edilen yaygın ve derin işbirliğini sağlamakta yetersiz kaldığına işaret etmektedir.

COVID-19 salgını, Türk Dünyası'nda ve İpek Yolu'nda planlanan turizm işbirliklerinin hayata geçirilmesinde bir engel olarak gösterilebilecek olsa da, tarihsel gelişimin incelenmesi, Türk Dünyası'nda turizm alanındaki işbirliğinin önündeki engellerin daha makro boyutlu olduğuna işaret etmektedir. Alanyazında yapılagelen tartı̧malardan yola çıkarak bu engeller; sektörel sorunlar, siyasi sorunlar ve ekonomik sorunlar olmak üzere üç ana başlık alında toplanabilmektedir. İmaj, tanıtım, turistik altyapı yetersizliği, ulaşımın uzun ve yorucu olması sektörel sorunlar, demokratikleşme, güvenlik, vize uygulamaları, taraflar arasındaki beklenti ve çıkar uyuşmazlıkları siyasi sorunlar (Polat, 2018); ülkelerin çok güçlü olmayan ekonomik yapıları ekonomik sorunlar başlığı alında toplanabilmektedir (Purtaş, 2011; Sancar, Kıngır, \& Soyalın, 2015; Türk, 2015). Söz konusu sorunlara yönelik olarak, alanyazında; turistik ürünlerin çeşitlendirilmesi, tanıtım ve imaj çalışmalarına ağırlık verilmesi, vize kolaylıklarının sağlanması, başta hava ve demir yolları olmak üzere üyeleri birbirine bağlayan ulaşım imkânlarının iyileştirilmesi, ortak turizm araştırma merkezlerinin kurulması, yatırımların çeşitlendirilmesi, turizm deneyimine sahip ülkelerin örnek uygulamalarından yararlanılması gibi öneriler getirilmiştir (Özdemir, 2009; Gülcan, 2016; Oktay, 2016; Polat, 2018; Zorlu, 2018). Yapilan öneriler UNWTO ve Türk Konseyi'nin çabaları ile paralellik sergilemektedir.

İpek Yolu Turu'nu kapsamına alan coğrafyanın büyüklüğü düşünüldüğünde, sektörel sorunların en önemlisi ulaşım ve maliyet sorunlarıdır. İpek Yolu Turu, tek bir tur paketi içinde gezilemeyecek kadar büyük bir coğrafi alanı kapsamaktadır. En uygun güzergâhlar saptansa dahi, destinasyonlar arasındaki mesafeler uzun ve yorucudur (Oktay, 2016). Üstelik bu kadar geniş bir alanda, tüm turistik çekicilikleri bir paket içine sığdırabilmek, sığdırılabilse bile tatmin edici bir sonuç elde etmek kolay değildir. Bu açıdan düşünüldüğünde tüm bölgeyi kapsayan bir ortak paket yerine, ülkelere özel paketler yapilması daha uygun olabilir. Ancak ülkeler özelinde planlanacak projelerin de kendi içinde operasyonel sıkıntıları olması kaçınılmazdır. Bölgenin turist gönderen gelişmiş ekonomilere olan uzaklığı göz önüne alındığında, ortak paket yerine her ülkenin ayrı ayrı gezilmesi, gidiş ve dönüşte harcanacak zaman ve para maliyetinin daha da artmasına, dolayısıyla, bazı ülkelerin ön plana çıkarken, diğerlerinin arka planda kalmasına neden olma 
tehlikesini de beraberinde getirmektedir. Bu durum ise tur paketi sayesinde ulaşllmak istenen ortak hedeflerden uzaklaşılmasına neden olabilecektir

Geniş bir coğrafyaya yayllmış, ortak tarih ve kültüre sahip ülkeler arasında işbirliğini geliştirmek, bunu yaparken de turizmden yararlanmak, modern dünyanın imkân ve ihtiyaçlarına uygun bir beklentidir. Buna rağmen Türk Dünyası'nda turizm alanında gerçekleştirilmeye çalışılan işbirliği arayışının, büyüklük ve etki açısından kıyaslanabileceği başka bir örnek yoktur ve bu denli çok sayıda ülkeyi kapsayan bir işbirliği arayışı dünyada ilk defa denenmektedir. İncelemenin ortaya koyduğu üzere süreç oldukça yavaş ilerlemekte ve istenen sonuçlar elde edilememektedir. Bu tespit turizmin arzulanan işbirliğinin gelişiminde birincil derecede öneme sahip bir konu olmadığı şeklindeki yorumu haklı çıkarmaktadır (Aydemir ve Yaşar, 2016: 57). Ekonomi, enerji ve güvenlik gibi alanlardaki işbirliğinin önündeki siyasi sorunların, turizm alanındaki işbirliği girişimleri için de olumsuz bir etkide bulunduğu anlaşılmaktadır.

İpek Yolu turizminin önündeki bir diğer büyük sorun ise özellikle Afganistan'daki son gelişmelerden sonra ortaya çıkan güvenlik sorunudur. Dünyada artan islamafobinin bölgeye yönelik uluslararası turizm hareketliliğini kısıtlayıcı bir faktör olması olasıdır. Dolayısıyla, imaj, tanıtım ve turistik altyapı yetersizliği gibi çözümü nispeten kolay sektörel sorunlar ortadan kaldırılsa bile, Türk Dünyası içinde turizm alanında işbirliği gelişiminin uzun zaman alacağı, bunun için mikro ve makro ölçekte yapisal değişimleri beklemenin gerekeceği söylenebilir.

\section{Etik Beyan}

"Türk Dünyasmmn Turizm Alanında İsbirliği Girişimleri: Bir Doküman Incelemesi” başlıklı çalışmanın yazım sürecinde bilimsel kurallara, etik ve alıntı kurallarına uyulmuş; toplanan veriler üzerinde herhangi bir tahrifat yapılmamış ve bu çalışma herhangi başka bir akademik yayın ortamına değerlendirme için gönderilmemiştir. Bu çalısma doküman analizine dayalı bir araştırma olduğu için etik kurul kararı zorunluluğu bulunmamaktadır.

\section{Kaynakça}

Aydemir, B. ve Yaşar, İ. (2016). Dış politika ve turizm ilişsisi bağlamında Türkiye’nin Asya ülkeleri ile yaptı̆̆ı turizm anlaşmalarının değerlendirilmesi. Ballkesir Üniversitesi Sosyal Bilimler Enstitiusü Dergisi, 19(36-1), 39-59.

Baki, P. M. (2014). Avrasya'da bölgesel işbirliği sürecinden işbirliği mekanizmasına: Türk Konseyi. Bilge Strateji, 6(11), $133-162$.

Bulut, Y. ve Gülcan, B. (2018). Kültürel yabancılaşmaya bağlı otantiklik arayışına Türk dünyası turizmi cephesinden bakış. MANAS Sosyal Arassttrmalar Dergisi, 7(4), 687-702.

Camgöz, C. (2019). Modern ipeke yolu projesi kapsammda Türk turizminin degerlendirilmesi (Yüksek Lisans Tezi). İstanbul Üniversitesi Sosyal Bilimler Enstitüsü, İstanbul.

Camgöz, C. ve İstanbullu Dinçer, F. (2017). Modern ipek yolu projesi çerçevesinde ulaştırma ağlarının turizme katkılar1. Yü̈zünciu Yal Üniversitesi Sosyal Bilimler Dergisi, 1(Özel Say1-3), 41-57.

Cumhuriyet (1992, 24 Şubat). Adriyatik'ten Çin'e Türkiye. Cumburiyet Gaæetesi E-Arşiv. Erişim Adresi: https://egazete.cumhuriyet.com.tr/oku/192/1992-02-24/1

Daban, C. (2017). Turgut Özal dönemi Türkiye diş politikası. Sosyal Ekonomik Araștırmalar Dergisi, 17(33), 77-96.

Deniz, T. ve Karadağ, D. (2019). Türk Dünyası'nın tanıtımında “modern ipek yolu ortak tur paketi”. Türk Turizm Arastrmalar Dergisi, 3(1), 93-110.

Dişişleri Bakanlığ (2021). Uluslararası antlaşmalar. Erişim Adresi: ua.mfa.gov.tr

Dinçer, M. Z, Bayram, A. T. ve Bayram, G. E. (2019). ISO 26000 standardı kapsamında Türk Dünyası ülkeleri konaklama endüstrisinin incelenmesi. Uluslararasi Insan Callsmalar Dergisi, 2(4), 234-248.

Göral, R. ve Tengilimoğlu, E. (2018). Türk Dünyası destinasyonlarının turizm sektörü etkinliğinin karşılaştırlması. Uluslararası Türk Dünyası Turizm Araştrmalar Dergisi, 3(2), 230-241.

Gülcan, B. (2016). Türk Dünyass ilişsilerinde kritik faktör olarak turizm. İçinde F.Atasoy (Edt.) Yükkselen İpek Yolu 1. Cilt, İpee Yolu'nda ekonomi ve turizm (ss. 113-120). Ankara: Türk Yurdu Yayınları.

Hasanov, R. (2015). The Turkic Council: A strong regional mechanism to enhance cooperation in Eurasia. İçinde Fifth summit of the Turkic Council: A rising actor in regional cooperation in Eurasia (ss. 1-4). Ankara: SAM.

Karadağ, D. ve Yavaşkan, Y. (2018). Türk dünyası kültür başkenti projesi’nin türkiye turizmine etkileri. Safran Kültür ve Turizm Arastrumalar Dergisi, 1(2), 71-78.

Mert, O. (2015). Türk Konseyi (Keneşi) Türk Üniversiteler Birliği ve Türk Üniversiteler Birliği I. Genel Kurulu. Atatïre Üniversitesi Türkiyat Arasturmalar Enstitiisï Dergisi, 53, 273-290.

Oktay, K. (2016). Organize ipek yolu turları üzerine bir inceleme. İçinde F. Atasoy (Edt.), Yükselen ipek yolu semposyumu 1. cilt: ipek yolu'nda ekonomi ve turizm (ss. 180-192). Ankara, Türkiye: Net Kitaplık Yayıncilık.

Oran, B. (Edt.). (2003). Türk Dış Politikası Cilt II: 1980-2001 (3. Baskı). İstanbul: İletişim Yayınları. 
Özdemir, N. (2009). Türk Dünyası kültür turizmi. İçinde Ü.Ç. Şavk (Ed.), 9. Türk Dünyası ekonomi, bilisim ve kültür forumu (ss. 155-174). Ankara: Hacettepe Üniversitesi Türkiyat Araştırmaları Enstitüsü Yayınları.

Polat, N. (2018, Nisan). Sille road tourism initiatives and their integration to global tourism system. 15th KIMEP International Research Conference, Special Joint Conference: The Silk Road and the Tourism and Hospitality Industries'de sunulan bildiri. KIMEP University- Almaty. Kazakhstan.

Purtaş, F. (2011). Orta Asya ile Güney Asya arasinda modern ipek yolu projesi: Afganistan, Pakistan ve Hindistan'en Orta Asya Türk. Cumburiyetleri ile iliskileri. Ankara: Hoca Ahmet Yesevi Uluslararası Türk-Kazak Üniversitesi.

Purtaş, F. (2017). Cultural diplomacy initiatives of Turkic Republics. Perceptions: Journal of International Affairs, 22(1), 91114.

Sancar, M. F., Kıngır, S. ve Soyalın, M. (2015). Orta Asya Türk Devletleri ile Türkiye arasındaki turizm potansiyeli ve ekonomi açısından incelenmesi. İçinde S. Sar1, A.H. Gencer ve İ. Sözen (Ed.), 6th International Conference on Eurasian Economies (ss. 291-297). Kazan, Rusya.

Turizm Günlüğü (2018). Turkic Council to promote the modern silk road joint tour package. Erişim Adresi: https://www.turizmgunlugu.com/2018/03/14/turkic-council-to-promote-the-modern-silk-road-joint-tourpackage/

Türk Keneşi (2014). First Meeting of Ministers of Turkic Council in Charge of Tourism will be held in Istanbul on 11 April 2014. Erişim Adresi: https://www.turkkon.org/en/haberler/first-meeting-of-ministers-of-turkiccouncil-in-charge-of-tourism-will-be-held-in-istanbul-on-11-april-2014_1

Türk Keneși (2015). Second Meeting of the Turkic Council Ministers in Charge of Tourism Hosted by the Ministry of Culture and Tourism of the Republic of Azerbaijan has concluded on 20th of May in Baku. Erişim Adresi: https://www.turkkon.org/en/haberler/second-meeting-of-the-turkic-council-ministers-in-charge-of-tourismhosted-by-the-ministry-of-culture-and-tourism-of-the-republic-of-azerbaijan-has-concluded-on-20th-of-may-inbaku_459

Türk Keneşi (2017a). Türk Konseyi Modern İpek Yolu Ortak Tur Paketi birinci tantım ziyareti Kayseri de başlamıştır. Erişim Adresi: https://www.turkkon.org/tr/haberler/turk-konseyi-modern-ipek-yolu-ortak-turpaketi-birinci-tanitim-ziyareti-kayseride-baslamistir_1252

Türk Keneşi (2017b). Türk Konseyi Modern İpek Yolu Ortak Tur Paketi birinci tanıtım gezisi 25-28 Nisan 2017 tarihlerinde Azerbaycan'da devam etmektedir. Erişim Adresi: https://www.turkkon.org/tr/haberler/turkkonseyi-modern-ipek-yolu-ortak-tur-paketi-birinci-tanitim-gezisi-25-28-nisan-2017-tarihlerinde-azerbaycandadevam-etmektedir_1261

Türk Keneşi (2018). Türk Konseyi Turizmden Sorumlu Bakanlar Toplantısı Astana da başarıyla gerçekleştirilmişsir. Erişim Adresi: https://www.turkkon.org/tr/haberler/turk-konseyi-turizmden-sorumlu-bakanlar-toplantisiastanada-basariyla-gerceklestirilmistir_1659

Türk Keneşi (2021a). Bakanlar/Çalışma Grubu Toplantıları. Erişim Adresi: https://www.turkkon.org/tr/isbirligialanlari/turizm_6/bakanlarcalisma-grubu-toplantilari_34

Türk Keneşi (2021b). Turizm. Erişim Adresi: https://www.turkkon.org/tr/isbirligi-alanlari/turizm_6

Türk Keneşi (2021c). Türk Konseyi Turizm Bakanları 6. Toplantısı Özbekistan'da düzenlendi. Erişim Adresi: https://www.turkkon.org/tr/haberler/turk-konseyi-turizm-bakanlari-6-toplantisi-ozbekistandaduzenlendi_2272

Türk, F. (2015). Türk Dünyasında turizmin gelişmesinde devlet dişı aktörler: Turizm acenteleri. Elektronik Siyaset Bilimi Arasttrmalar Dergisi, 6(11), 97-105.

Türkiye Cumhuriyeti Hükümeti ile Azerbaycan Cumhuriyeti Hükümeti arasında turizm işbirliği anlaşması. (1992, 1 Kasım). Resmi Gazete (Sayı: 21474). Erişim adresi: http://ua.mfa.gov.tr/detay.aspx?4671

Türkiye Cumhuriyeti Hükümeti ile Özbekistan Cumhuriyeti Hükümeti arasında turizm alanında işbirliği anlaşması. (1992, 5 Ekim). Resmi Gazete (Sayl: 21553). Erişim adresi: http://ua.mfa.gov.tr/detay.aspx?4703

Türkiye Cumhuriyeti Hükümeti ile Türkmenistan Devleti Hükümeti arasında turizm işbirliğ̣i anlaşması. $(1992,19$ Ağustos). Resmi Gazete (Sayl: 21553). Erişim adresi: http://ua.mfa.gov.tr/detay.aspx?4704

Türkiye Cumhuriyeti ile Kırgızistan Cumhuriyeti arasında imzalanan turizm işbirliği anlaşması. (1992, 7 Ekim). Resmi Gazete (Sayl: 21553). Erişim adresi: http://ua.mfa.gov.tr/detay.aspx?4702

UNWTO (1994). The Samarkand Declaration on silk road tourism. Erişim Adresi: https://webunwto.s3.eu-west1.amazonaws.com/s3fs-public/2019-11/samarkanddeclaration1994new.pdf

UNWTO (1999). Khiva Declaration. Erişim Adresi: https://webunwto.s3.eu-west-1.amazonaws.com/s3fspublic/2019-11/khivadeclaration1999.pdf

UNWTO (2002). The Bukhara Declaration on silk road tourism. Erişim Adresi: https://webunwto.s3.eu-west1.amazonaws.com/s3fs-public/2019-11/bukharadeclaration2002.pdf

UNWTO (2009). Astana Declaration. Erişim Adresi: https://webunwto.s3.eu-west-1.amazonaws.com/s3fspublic/2019-11/astanadeclaration2009.pdf

UNWTO. (2010a). Shiraz Declaration. Erişim Adresi: https://webunwto.s3.eu-west-1.amazonaws.com/s3fspublic/2019-11/shirazdeclaration2010.pdf

UNWTO (2010b). Towards a stronger silk road brand. Erişim Adresi: https://webunwto.s3.eu-west1.amazonaws.com/imported_images/29648/5th_international_meeting_on_the_silk_road_conclusions_eng.p $\mathrm{df}$ 
UNWTO (2014). Silk road action plan 2014/2015. Erişim Adresi: https://webunwto.s3-eu-west1.amazonaws.com/imported_images/40541/silkroadactionplaningles.pdf

UNWTO (2016). Silk road action plan 2016/2017. Erişim Adresi: https://www.silkroad-adventures.com/wpcontent/uploads/2018/05/sr2016web.pdf

UNWTO (2018). 8th UNWTO silk road task force meeting. Erişim Adresi: https://www.unwto.org/europe/event/8th-unwto-silk-road-task-force-meeting

UNWTO (2021a). Background of the Global Code Of Ethics For Tourism. Erişim Adresi: https://www.unwto.org/background-global-code-ethicstourism\#: :text=The $\% 20$ Global $\% 20$ Code $\% 20$ of $\% 20$ Ethics $\% 20$ for $\% 20$ Tourism $\% 20($ GCET) $\% 20$ is $\% 20$ a,visit ors $\% 2 \mathrm{C} \% 20$ both $\% 20$ international $\% 20$ and $\% 20$ domestic

UNWTO (2021b). Technical cooperation and silk road-declarations. Erişim Adresi: https://www.unwto.org/declarations-silk-road

Yılmaz, B. A. (2019). Soğuk Savaş sonrası Türk-Orta Asya ilişkilerinde Türk Keneşi’nin rolü: Dönemler ve değişim dinamikleri. Barnş Araștırmalar ve Catısma Cö̈zümleri Dergisi, 7(1), 1-25.

Zorlu, K. (2018). Türk Dünyasında turizm işbirliğinin geliştirilmesine yönelik bir araştırma. Journal of Tourism and Gastronomy Studies, 2(9), 182-199.

\section{EXTENDED ABSTRACT}

Tourism is one of the most important areas of cooperation in joining the economies of the Turkic world as well as in widespread and firm coalescing among the relevant states. Other than bilateral agreements between parties, the notable sources that make pursuits of cooperation in the field of tourism apparent are the declarations signed at the conclusion of the Summits of Turkic Speaking States Heads in 1992-2010; the resolutions adopted by the Turkic Council, which was founded in 2011; the meetings held among the Ministers of Tourism Affairs; and, as an external factor, the UNWTO initiatives.

The first substantial project as an effort to develop cooperation in tourism was "Reviving the Historic Silk Road; Development of Cultural Tourism, Revitalization, Protection, and Stable Development of the Cultural Heritage of Turkic Speaking States" a program brought up at the fourth Summit of Turkic Speaking States Heads in 1996.

The Turkic Council's fourth summit, named "Tourism Cooperation", convened in 2014, at which an important objective for the Turkic world was determined to be turning the historic Silk Road into an attractive tourism destination. As an evidence, the idea of "Silk Road Joint Tour", initially brought forward in 1996, was actualized by virtue of the tourism theme of the 2014 Summit, and the most concrete step in collaborative tourism in the Turkic world was taken by way of the "Modern Silk Road Joint Tour Package." The Modern Silk Road Tour Package aims to promote the region worldwide as well as make tourism a significant means of economic development of the region.

The preparation phases of the Modern Silk Road Joint Tour Package included signing the "Joint Cooperation Protocol on Tourism Cooperation among the Member States" in 2014, followed by the establishment of a "Task Force" in 2018 to operationalize the project, in addition to the signing of the "Cooperation Protocol among the Private Sector Umbrella Institutions of the Member States" and the UNWTO Global Code of Ethics for Tourism in 2015 and 2016, respectively.

UNWTO has also been making great efforts in boosting the Silk Road tourism. The importance attributed to tourism in socio-economic development has made UNWTO an influential actor of regional development plans and, consequently, one of the organizations endeavoring mostly for advancing tourism along the Silk Road. While focusing on different objectives, the five declarations adopted by UNWTO place emphasis on cooperating to achieve regional prosperity and stability, creating a powerful tourism brand through distinct stakeholders' united efforts, and developing a concept of tourism that highlights natural as well as cultural assets of the region. Upon failure of other actors to take concrete steps by 2010, UNWTO took a new turn with a series of action plans. Efforts since 2010 to further the Silk Road tourism can be traced via action plans published by UNWTO on various dates and activities of the Task Force. Three focus areas were determined as a part of the 2014 action plan: marketing and promotion, destination management and capacity building, and travel facilitation (UNWTO, 2014). In 2018, the Task Force with 35 member-states began seeking a new philosophy and action plan; instead of one-way, topdown strategies, setting courses for tourism development on a country-by-country basis by means of 2-4 year projects compatible with own priorities and interests was proposed. 
The most substantial endeavors to collaborate in the field of tourism of the Turkic world have been the UNWTO Silk Road Program and the Turkic Council's Modern Silk Road Joint Tour Package initiative; efforts to operationalize the latter accelerated in the recent years but came to a standstill because of COVID-19 as they were about to go into action.

Despite all efforts done by both UNWTO and the Turkic Council, the desired outcome of the Modern Silk Road Joint Tour Package, the most concrete project so far, could not be achieved. Difficulties the Turkic world countries face might be grouped into three types: industry-specific issues such as image, lack of promotion and tourism infrastructure; political problems such as democratization, safety, visa requirements, conflicts of expectations and interests among the parties; economic obstacles such as tiring, long-distance journeys and being listed as developing countries. These three types of difficulties have adverse effects on the international tourism towards the Turkic world equally as the tourism movements within the Turkic world itself. Solutions are diversifying tourism products; concentrating on promotion and image-building; easing visa requirements; improving transportation facilities, particularly airlines and railroads, that interconnect the member countries; establishing joint tourism research centers; expanding investments; drawing on model practices of countries with considerable tourism experience; which parallel propositions and endeavors of UNWTO and the Turkic Council. Various developments since 1996 indicate, however, that overcoming problems that face cooperation in tourism in the Turkic world has been and will continue to be challenging. 